\title{
The Influence of Digital Technologies on Performance of Work and its Legal Regulation
}

\author{
Silvia Trelova ${ }^{1}$ and Lenka Prochazkova ${ }^{2}$ \\ ${ }^{1,2}$ Comenius University in Bratislava, Faculty of Management, \\ Odbojárov 10, 82005 Bratislava, Slovak Republic \\ silvia.trelovalfm.uniba.sk
}

\begin{abstract}
The start of the digital era in the light of the fourth industrial revolution has brought new models of flexible working within the employment sphere. The traditional models of employment relationships have been augmented by new forms of working. The paper deals with forms of dependent work influenced by digital technologies and it deals with the protection of such an employee. It also outlines ways of working while using digital collaborative platforms carried out by a physical entity independently and flexibly. The influence of digitalization on the labour market is undeniable and when applied new challenges arise which have to be also dealt with by Slovak employment legislation. Which legislative changes are necessary and which fields of law they will concern is a subject of expert discussions and analyses.
\end{abstract}

Keywords: Digitalization, Flexible work, Collaborative Platforms, Telework, Smart Work, Crowdwork.

\section{Introduction}

In the past three decades, there has been a rapid development of technologies and gradual digital transformation has also shown in the employment sphere. The digitalization of work processes leads towards an extension of forms of working and organization of work bringing new ways and models. The existing standard forms of employment are extended by newly created more flexible work forms that support innovation, creation of jobs and the growth of labour market. This also calls for changes in legal regulations of labour law, not only within European standards but also domestic, to ensure work, social and legal protection of working people. The need for legislative changes is also faced by Slovak labour law, which must deal with the new elements that the development of the collaborative economy brings to labour law. That is what the fourth industrial revolution also brings. 


\section{Models of work performed under the influence of digitalization}

Companies are implementing innovative work methods. New models of working are characterized by high flexibility (the subordination principle typical for dependent work is being considerably weakened) and by independence, which leads to individualization of the subject (physical entity is not included in the collective of company employees). Modern information and communication technologies made the performed work more flexible, they disposed of space and time which is mirrored also in the change of work content. This trend also brings non-standard work conditions. The rise of new forms of working is a reaction to the demand for applied practice taking the form of more flexible work relationships, however, there is a rising risk of lowering social standards and lowering or even loss of legal protection of working physical entities. It is the task of lawgivers to set the legal regulation for equal and fair treatment in the labour market and to ensure the social assurance of people.

\subsection{Teleworking and smart working}

The longer and most commonly used form of performed work is teleworking or "working remotely“. It is the only way of work activity done through information and communication technologies, which is regulated by Slovak law - $\S 52$ Labour Code [1]. Telework represents a form of working organized within typical employment with the place of work - the household of the employee (homeworking). Telework is most commonly performed from home but it is possible to do it in another place which is agreed upon in the employment contract as the place of work. This means that telework has the character of dependent work whose specific feature is that it is not done in the workplace of the employer, the employee himself schedules his working hours set by the employer for the week (working hours per week stated in his employment contract are valid) and regulations on continuous daily rest, as well as continuous weekly rest, do not apply. Some wage titles do not apply to a teleworking employee such as overtime payments, wage compensation for working during a state holiday, wage compensation for working on Saturday, wage compensation for working on Sunday, wage compensation for working during the night and wage compensation for difficult work conditions. These wage claims can be agreed upon between the employer and teleworker in the employment contract. Regulations on obstacles to work apply to a teleworker in the same way as a regular employee. However, this is not true about idle time on the side of the employer. If an important personal obstacle to work arises on the side of the teleworker, during this time he is not entitled to wages from the employer. The only exception in these obstacles is the death of a family member.

Since teleworking is unavoidably based on the use of information and communication technologies, the employee needs the necessary technical equipment to be able to work. If the employee is not going to use his own equipment, the employer has to provide the necessary technical and software equipment and maintain it on a regular basis. The employee has to be notified by the employer about any limitations on the use of 
this equipment and also about any sanctions arising from not obeying the rules on limitations. The inherent part of employer obligations is the protection of processing and the use of data.

The employer is responsible for observing the security and protection of health during the work of the teleworker. Since the employee works with the display screen equipment, the employer has to observe the related minimum security and health claims regarding the machine and keyboard, further work instruments, environment and employee interaction with the work instruments. [2] When doing telework we encounter several problems, especially connected to controlling the employee by the employer in the home environment (the household of the employee is the most usual place of work), which is linked to the issue of protection of personality and privacy of the employee.

Minimal social contacts of the teleworker are a common feature of teleworking. For the teleworker, it is typical that he is pulled out of the collective of employees working in the workplace of the employer, and that is why the employer is to avoid this isolation through such measures which will enable the teleworker to meet personally other employees (e.g. regular meetings, team buildings).

In real life, we encounter other forms of remote working. Smart workers also use a modern form of working. Smart working or "intelligent work" is work done without exactly set time (highly flexible working hours), while the smart worker works using technological tools from any place in the world. The aspect of time a place of work is irrelevant; it is the result of the work of the physical entity which is important.

The term smart working is often identified with teleworking. An analysis of the Estonian Advice Centre dealt with comparing these terms in the year 2012 and specified that the initial concept of telework has been developed into that of smart work. The technological developments of telework changed the form of work but the content of work remained the same. In smart work, it is the content of work that has changed, from work cultures to communication and from organizational structures to premises. The relationship between the employer and employee has changed to subordination and opposition to that of collaboration and co-operation, with both sides having a larger degree of liberty but of responsibility as well. They act as partners in entrepreneurship. [3] In smartworking, the employee's dependence is significantly weakened. Smart working focuses on "effectivity and time management with regard to the final product and that is such a way that it offers the employee a greater space for autonomy than with standard employment done in workplace premises which leads to an overall change of work culture, area as well as relationships between the employee and employer." [4] Seilerová states that "teleworking is seen as a pre-stage of smart working. It is often also denoted as a new form of teleworking." [5] It may be stated that even though both forms of modern work performance lead towards delocalization of the workplace, it concerns individual categories, different terms with different content, even though they are very close and the intelligent work system as a form of organizing employment is not directly regulated by Slovak law. 


\subsection{Crowdworking and models of the collaborative economy}

Crowdworking can be also included among the new kinds and ways of working. We are talking about a new way of working performed freely online. This is a position of crowdworkers whose work is highly independent (directions for performing the work are minimal) and highly flexible (work is done from any place and at any time). A crowdworker is not part of the company structure. The concept of crowdworking rests upon the entrepreneur as a consumer of the performed work "entering the piece of work in the 'crowd' within an online internet platform and the individual can freely choose if he supplies the demanded work and at what price." [6] Even though the status of the working individual is questionable in the view of the character of his work (whether this is an employee or freelancer), individuals like to use the possibility to work through crowdworking and profit from it. The crowdworker can work for one or several entities.

As H. Barancová states, "especially representatives of employees on the European level have significant reservations towards crowdworking and they consider this way of working exploiting", and at the same time the unethical competition of individuals in labour cost in the online mega-trade market is criticised [6]. With regard to the character of work, the crowdworker does not have regular income secured if he does the work as a self-proprietor.

Under the influence of the digital era a wide range of models of collaborative economy ("sharing economy") [7] come to be, it is especially true about the field of services that are becoming more available (a principle of mobile application). The work is performed through digital platforms and in this working model, three entities take part the collaborative platform in the position of mediator of services, the service provider and user of services as the receiver of service. The number of entities is the untypical element of a labour relationship. The service provider freely decides when and how often he would do the work.

When we look at the status of the service provider, his status in the different models of a collaborative economy is either an employee or a self-proprietor, nevertheless, in some cases his position is unclear. It has to be stressed here that legal regulation of some collaborative methods of working is not outright, which is evidenced by trials with the American company for a shared ride Uber. Even though Uber has long reasoned that it is only a platform which connects drivers and travellers (drivers are seen as partner drivers), London employment tribunal and employment appeal tribunal in the trial of Aslam, Farrar v Uber [8] decided that the relationship between the driver of the digital platform and the mediator (Uber platform) is an employment relationship. In the judgment, 13 facts are set out (paragraph 92) which prove the existence of dependent work and fulfil the characteristic of subordination of the employee and paid personal performance of work on behalf of the employer. Although "due to the absence of labour wage institutes, it is not possible to speak unambiguously about the fulfilment of the wage sign in the labour law sense ... the truth remains that the income of digital platform drivers de facto comes from a relationship characterized by other signs of dependent work and may therefore be a de facto wage." [14] The court questioned the mechanism created by Uber for the purpose of creating the impression that the drivers are selfproprietors using the offered technology for better access to job opportunities. [9] The 
Supreme Court in France held a similar view of the employment relationship which decided in March 2020 that one of the former drivers was in fact an employee. The court reasoned in the decision by the fact that the company Uber had control of the driver through his connection to the application which led him to clients. This is the reason why the service provider should be considered an employee, not an independent subcontractor. We identify with this view and ask the question: If there is a work interview with the Uber drivers, if the route is given to the driver by an application, if Uber sets fixed prices of transportation, if drivers receive internal instructions, where is the high level of autonomy of the entity, which is so typical for sharing economy? This verdict could thus mean a breakthrough and thereafter influence all platforms inspired by the Uber model (e.g. Taxify).

\section{Socio-legal aspect of work performance using modern technologies}

The social-legal aspect of performed work using modern technologies can be seen positively as well as negatively. On one hand, digitalization makes performing of work easier (the possibility to work from different places, the possibility to adjust the time of work, the possibility of the better interconnection of work and family life), however a need of constant education in IT arises (using digital tools and programs), while not everyone is technologically adept and this can lead to frustration (especially for those in higher age group). An important aspect that is also the negative one of remote work, is that new risks arise which are connected to the application of rights and social protection of concerned workers (jobholders). The loss of personal contacts and isolation of the individual may also be seen negatively.

Even though the aim of remote work (especially telework) is not working more hours, the possibility to log in and communicate from any place and whenever interferes with the rights of an employee. Often the employee spends more time working which goes over the legally stated limits on working hours and by that also the time for rest. Since modern technologies allow never-ending/permanent availability of the employee, the work-life of the employee often pervades the private life. There are just a few employees who are so disciplined that after working hours they would be able to ignore work phone calls, text messages, work e-mail. This wipes the typical model of working day and we almost cannot say when it starts for us and when the working hours end. Also, Križan says that working hours "thanks to the phenomenon of information technologies are starting to increase. An employee working with information technologies often remains available for the employer after the end of his working hours and during this time he continues to work through discussions or email communication to solve problems" [10]. It can be stated that modern technologies not only influence the length of working hours but also its organization since many employees continue to communicate for work in the evening hours or weekends or holidays.

Working hours are becoming uncontrollable for us which also leads to different mental problems - overstrain of the employee connected to exhaustion, even burnout syndrome 
[11], disruption of family relationships, health problems (insomnia, digestion problems, obesity ...) and the physical entity is becoming a victim of social isolation.

\section{$4 \quad$ Legal regulation of digitalized working relationships}

The development of new forms of working as a result of digitalization is developing dynamically, new legal situations arise and this should be also reflected in legal regulations of these working relationships which, however, is absent. A very important question arises: What legal regulation should cover these modern relationships which come to be when performing work? If we consider that these physical entities should perform these non-standard ways of work in the regime of labour law or commercial law, we incline to the first option so that this physical entity could keep its protection, labour as well as social-legal (the existence of minimum wage, protection of health during work, a food contribution, the existence of work hindrances, etc.). If the performance of digital forms of work were outside the employment relationship, the physical entity would lose the rights following from labour law and social law.

From the point of view of current legislation, the performance of work is considered either dependent work with significant social protection or work that is regulated by other private codes, de facto without any social protection of the persons who perform it. At the same time, the performance of work, which is somewhere on the border between independence and dependence, is not specially regulated. [12] We presume that it is necessary to embed into the union law and by that also the in-country regulation some freer employment relationship. In our opinion performing work in a digital form should be the subject of labour law, and that especially in connection with legal employment protection of these persons. The field of social-legal protection would be reduced concerning the character of performed work.

As H. Barancová states, in this regard, there is a lack of defined boundaries between the term of an employee and freelancer. She gathers that physical entities performing digital forms of working should belong to a rather independent employment category, inter-category between the term of employee and freelancer, which points at making the existing term of an employee more flexible. [13]. The category employee and freelancer do not suffice anymore because a person working in a modern way does not have a status like a regular employee neither a regular freelancer.

\section{Conclusion}

The fourth industrial revolution which brings many challenges into the lives of societies represents a trend of digitalization, which is connected with changes in the field of employment. Work, where it is technologically possible and meaningful, is becoming remote work.

The omnipresent technological development brings newer and newer forms of working. Today these are not only untypical forms of employment as fixed-term contract jobs or working fewer hours, or even more modern forms of telework. Modernization goes ahead, smart working, crowdworking are used and as we state at the end the new 
phenomenon in the past few years has been the development of the sharing (collaborative) economy and connected new models of working. The aim of sharing economy should primarily be sharing of costs not gaining profits. It is necessary to analyse the individual forms, compare them and assess the relationships between suppliers of work and consumer of work. If, on the basis of analyzes, even a certain degree of dependence on the performance of work in some models of the collaborative economy is proved, the given performance of work must be subsumed under the employment relationship. Although such performance has certain specifics, it will be an atypical employment relationship that needs its legislative regulation, and the legislator is expected to make the most appropriate legislation. An appropriate way of legal regulation will prevent the concealment of employment relations.

The pace of implementation of new forms of working and the pace of changes in employment legislation is in total disproportion. While the new forms of working develop dynamically, their legal regulation remains the same, is inadequate, or in certain cases even is absent.

In the case of new methods of performing work in the online world, there are arguments among the expert public about the essence of the legal relationship, whether to subordinate the performed work under the labour or commercial law. The legal regulation of this employment relationship in the Slovak Republic is non-existent even though there is a necessity to legally regulate this as a result of nowadays general use of it. It is necessary to make a profile of the status of a physical entity performing their work online because it is not a typical employee nor a typical freelancer. "Acknowledging a particular legal status accompanied with a certain level of social-legal protection would mean extending the subject of labour law by 'economically' active employees who would not be subject to complex legal employment protection in the same way as standard employees due to their way of work and level of independence and on the other hand they would be protected more than self-proprietors because they do not perform freelance work, do not dispose of own capital and by that are not exactly freelancers or self-employed individuals. The given legal models for the inter-category of an employee and self-proprietor is known in other countries. They are used e.g. in Germany, Austria, Switzerland or Sweden. The given inter-category is specified in expert literature as a category of 'economically dependent employees' or 'dependent suppliers or secondary supplier'." [6] Such persons similar to employees do not belong to a category of employees from the point of view of their involvement neither a category of freelancers (self-proprietors). [14]

M. Rusnák inclines to a novelization of the Labour Code in the form of special regulations that would deal with employees of digital platforms, similarly as it is with telework or employment through agencies. Special regulations of the Labour Code could attend to the objective absence of working hours as a sign of dependent work, which is embodied in such work. [15]

Another possible solution to the application problems is to extend the basic term 'dependent work' from labour law according to the Labour Code, which means that some chosen relationships within the digital platforms called collaborative economy will be subsumed under the term of dependent work. Such legal regulation could pre- 
vent veiling the employment relationships by other relationships following the commercial law, which would ensure the protection function of the labour law concerning the suppliers of services. "Well-set employment regulations of newly arising relationships can contribute to content "clearance" of the term of the collaborative economy... so that this term could not hide a business plan of digital platform owners, where suppliers of services work deprived of employee protection and at the same time deprived of the freedom of a self-proprietor." [15]

If such a legal employment regulation did not come to be or based on analyses a conclusion was drawn that an employment relationship cannot be used, it would be necessary to extend the basic term of the commercial law - 'self-proprietorship' following the Commercial Code and 'self-employed entrepreneurship' following the Trade Act. Redefining some basic terms is inevitable today.

According to the statements of the state secretary of the Ministry of Labour, Social Affairs and Family Branislav Ondruš "any future legal scope should meet two conditions: it should not hinder the development of digital technologies and at the same time it should not lead towards lowering social standards of working people." [16]

Although we point to the in-country legal regulation, with regard to the use of digital forms of working in different countries it is indisputable that the subject legal regulation should not only come to be on the level of the Slovak Republic but also it should be unified within European employment legislation, as it is for example regarding e.g. working hours, safety and protection of health during work, maternity and parental leave. European legislation should embed minimal requirements and basic boundaries of performing such work by a more specific regulation that would be accepted on the level of national legislation.

\section{References}

1. Law No. 311/2001 Coll. Labour Code as amended later

2. Directive No. 90/270/EHS, Government regulation SR No. 276/2006 Coll.

3. Modern Work Forms - from Telework to Smart Work. Analysis, Estonian Advice Centre, 2012, http://www.micropol-interreg.eu/IMG/pdf/Report_-_Modern_work_forms__from_telework_to_smart_work-2.pdf, last accessed 2020/06/06.

4. Macko, L.: Práca z domu - možnost', nevyhnutnost' či výhoda? In: Barinková, M. (ed.): Ochrana zamestnanca perspektívou priemyselnej revolúcie 4.0. Košice: Vydavatel'stvo ŠafárikPress UPJŠ v Košiciach, pp. 28-48, 2019, https://dusevnezdravie.upjs.sk/wp-content/uploads/2019/11/ochrana-zamestnanca-s-perspektívou-priem-revolucie-final.pdf, last accessed 2020/06/07.

5. Seilerová, M.: Formy a spôsoby výkonu práce pri použivaní informačno - komunikačných technológií a ochrana zdravia pri práci. Práca 4.0, Digitálna spoločnost' a pracovné právo, pp. 61-83, Bratislava 2018, https://dusevnezdravie.upjs.sk/wp-content/uploads/2019/11/ochrana-zamestnanca-s-perspektívou-priem-revolucie-final.pdf, last accessed 2020/06/06.

6. Barancová, H. : Nové technológie v pracovnoprávnych vzt’ahoch. Praha: Leges, (2017) 
7. Tippet, E.: Employee Classification in the Sharing Economy. [book chapter, Cambridge Handbook of Law and Regulation of the Sharing Economy]. 2017, https://www.researchgate.net/publication/318991119_Employee_Classificatio n_in_the_Sharing_Economy, last accessed 2020/06/11.

8. The court decision Aslam, Farrar v. Uber B. V., https://www.judiciary.uk/wp-content/uploads/2016/10/aslam-and-farrar-v-uberreasons-20161028.pdf, last accessed 2020/06/10.

9. Freedland, M., Prassl, J.: Employees, workers and the 'sharing economy' Changing practices. Spanish Labour Law and Employment Relations Journal. EISSN 2255-2081 29 N.o 12, Vol. 6, November 2017, pp. 16-29, https://doi.org/10.20318/sllerj.2017.3922, last accessed 2020/06/11.

10. Križan, V. Pracovný čas zamestnancov pracujúcich s informačnými a komunikačnými prostriedkami. In: Barancová, H., Olšovská, A. (eds.): Priemysel 4.0 a pracovné podmienky. Praha: Leges, (2018)

11. Trel'ová, S.: Výkon práce pomocou informačno-komunikačných technológií a syndróm vyhorenia. In: Pracovné právo v digitálnej dobe. - Praha : Nakladatelství Leges, pp. 169179. (2017)

12. Dolobáč, M. Legislatívne výzvy priemyselnej revolúcie 4.0. In: Švec,M,, Bulla, M. (eds.). Práca 4.0, digitálna spoločnost' a pracovné právo. Bratislava (2018)

13. Barancová, H., Olšovská, A. (eds.): Priemysel 4.0 a pracovné podmienky. Praha: Leges, (2018)

14. Dolobáč, M.: Zastretý pracovný pomer. In: Žulová, J. Pracovnoprávne elementy výkonu (závislej) práce - Kritika a deformácia práva. Košice: Univerzita Pavla Jozefa Šafárika v Košiciach. (2015)

15. Rusnák, M. Kolaboratívna ekonomika a jej vplyv na pojem závislá práca. In: BARINKOVÁ, M. (ed.): Ochrana zamestnanca perspektívou priemyselnej revolúcie 4.0. Košice: Vydavatel'stvo ŠafárikPress UPJŠ v Košiciach, 2019, p. 24, https://dusevnezdravie.upjs.sk/wpcontent/uploads/2019/11/ochrana-zamestnanca-s-perspektívou-priem-revolucie-final.pdf, last accessed 2020/06/09.

16. Práca a digitálne technológie: nebrzdit', no chránit'. https://euractiv.sk/section/veda-a-inovacie/news/praca-a-digitalne-technologie-nebrzdit-no-chranit/, last accessed 2020/06/11. 